\title{
Magnetic Mesoporous Silica Composite for Enhanced Preconcentration of Selected Organophosphorus Pesticides in Fruits
}

\author{
Nur Husna Zainal Abidin, Wan Nazihah Wan Ibrahim*, Nor Suhaila Mohamad \\ Hanapi, and Nor'ashikin Saim
}

Faculty of Applied Sciences, Universiti Teknologi MARA, 40450 Shah Alam, Selangor, Malaysia

\author{
*Corresponding author: \\ email: wannazihah@salam.uitm.edu.my
}

Received: January 23, 2019

Accepted: June 12, 2019

DOI: $10.22146 /$ ijc.42935

\begin{abstract}
In the present work, MCM-41 coated magnetic particles $\left(\mathrm{Fe}_{3} \mathrm{O}_{4}-\mathrm{MCM}-41\right)$ composite was synthesized and employed as an effective adsorbent in magnetic solid phase extraction (MSPE) of three selected organophosphorus pesticides (OPPs) namely chlorpyrifos, diazinon and parathion methyl from grape and strawberry samples prior to high performance liquid chromatography with UV detection (HPLC-UV). The synthesized sorbent was physicochemically and morphologically characterized via Fourier transform infrared spectroscopy (FT-IR), field emission scanning electron microscopy (FESEM), transmission electron microscopy (TEM), X-ray diffraction (XRD) and $\mathrm{N}_{2}$ adsorption analysis. The main parameters on the extraction efficiency of selected OPPs, including extraction time, desorption solvent, desorption time, and sorbent dosage, were thoroughly optimized. Compared to MCM-41 sorbent, the newly synthesized $\mathrm{Fe}_{3} \mathrm{O}_{4}-\mathrm{MCM}-41$ adsorbent shows a linear response (0.1-5.00 $\left.\mathrm{mg} \mathrm{L}^{-1}\right)$ with good determination coefficients ranging from 0.9900 to 0.9980 , low limits detection (LODs), 0.02-0.15 $\mathrm{mg} \mathrm{L}^{-1}$ and low limit quantifications (LOQs), 0.06-0.40 $\mathrm{mg} \mathrm{L}^{-1}$. The precision as relative standard deviation (\%RSD) of the proposed MSPE method was studied at low and high concentration (0.1-5.0 $\mathrm{mg} \mathrm{L}^{-1}$ ) based on intra-day (1.0 to 6.0\%, $n=3$ ) and inter-day (1.0 to $7.0 \%, n=3)$, respectively. Fruit matrices were used to assess the field applicability of the sorbents. Comparatively, $\mathrm{Fe}_{3} \mathrm{O}_{4}-\mathrm{MCM}-41$ achieved excellent percent recovery (85-120\%) compared to the MCM-41 (70-110\%). The result revealed that the $\mathrm{Fe}_{3} \mathrm{O}_{4}-\mathrm{MCM}-41$ composite was efficient sorbent with good capability for the preconcentration of selected OPPs from fruit samples.
\end{abstract}

Keywords: $M C M-41 ; \mathrm{Fe}_{3} \mathrm{O}_{4}-\mathrm{MCM}-41$; organophosphorus pesticides; magnetic solid phase extraction

\section{- INTRODUCTION}

In recent years, the pesticide has been remarkably increased in usage for better agricultural practices, transparency, and traceability in the production and marketing of conventional food. Generally, organophosphorus pesticides (OPPs) are widely used as insecticides in agriculture activities, which lead to extensive contamination of water, atmosphere soil as well as agriculture products and eventually in derivate food commodities [1] due to their desirable properties such as biodegradable and short persistence in the environment [2]. Particularly, fruit commodities contaminated by
OPPs, including grape, tomato, strawberry, apple, and pineapple [3-6], are becoming the hottest issue for environmental researchers because it can threaten human health. Grape and strawberry are usually freshly consumed without peeling, which risks harmful to human health because some of them have high acute toxicity due to the prevention of neural impulse transmission by their inhibitions of acetyl cholinesterase function in the nervous system [7]. Due to the high toxicity at low concentration, European Union (EU) have established maximum residue limits (MRLs) of various pesticides in grape and strawberry samples in the range of 0.01 to $0.05 \mathrm{mg} \mathrm{L}^{-1}$ [8]. Consequently, due to the

Nur Husna Zainal Abidin et al. 
exceeded permitted level by regulation as well as wellknown toxicity of OPPs pesticides and their degraded products, effective extraction coupled with appropriate clean-up and enrichment steps are necessary prior to instrument analysis [9-11].

Several techniques including, liquid-liquid extraction (LLE) [12], solid phase extraction (SPE) [13], solid phase microextraction (SPME) [14], micro solid phase extraction ( $\mu$-SPE) [15] and dispersive solid phase extraction (DSPE) [16] have been successfully applied to remediate the pesticides and their degraded products from the various matrices. Comparatively, the SPE method offers good recovery, short extraction time, high enrichment factor, less organic solvent consumption, and reasonable cost is eminent as an advantageous and genuine method [17-19]. However, there are several limitations encountered of this method, including a large amount of eluent, time-consuming, due to the limited rate of diffusion and mass transfer and limited efficiencies of the target analytes from large breakthrough volume [18]. Thus, the development of novel SPE models by applying magnetic nanoparticles as the SPE sorbent known as magnetic solid phase extraction (MSPE) are highly sensible.

In recent years, magnetic solid phase extraction (MSPE) a pioneering technique for sample preparation as well as performed a great interest in order to improve the stability, sensitivity, compatibility, and good extraction efficiency. It is a new mode of SPE based on the adoption of magnetic or magnetizable adsorbents which can be readily isolated from the sample matrix by an external magnet without any filtration or centrifugation [21-22]. Notably, magnetic sorbents are uniformly dispersed into suspension by vortexing or shaking to enhance the interfacial area between sorbent and analytes, which give high extraction efficiency in a short time $[20,22]$.

Hitherto, $\mathrm{Fe}_{3} \mathrm{O}_{4}$ nanoparticles have been widely used as a sorbent in MSPE due to its high magnetic saturation, low toxicity, and simple preparation process [23]. However, as their high surface area (10 to $\left.450 \mathrm{~m}^{2} \mathrm{~g}^{-1}\right)$, the unprotected metal oxide nanoparticles have a great tendency to aggregates, less surface interaction and easily oxidized $[23,25]$. These drawbacks can overcome through functionalization or coating with different compounds for pre-concentration trace level of organic pollutants [24-26]. To date, silica/magnetite nanocomposites have been particularly devoted, since the protective layer afforded by silica can screen the dipolar magnetic attraction between magnetite particles, which favor the dispersion and prevent them from leaching in the acidic environment [27].

In this regard, mesoporous silica such as MCM-41 (Mobil Composition of Matter Number 41), and SBA15 (Santa Barbara Amorphous-15) are solid materials, as well as consist of a honeycomb-like porous structure with hundreds of free mesopores that are able to accommodate relatively with high coverage of bioactive molecules. Their tremendous features, include high surface area (700-1500 $\left.\mathrm{m}^{2} \mathrm{~g}^{-1}\right)$, large pore volume $\left(>0.7 \mathrm{~cm}^{3} \mathrm{~g}^{-1}\right)$, tunable pore size with a narrow distribution, and good chemical and thermal stability of these materials, make them potentially suitable for various application in different fields of technology including drug delivery system [28], catalysis [29], sensing [30] and removal/preconcentration of organic pollutants [30-32]. Furthermore, a huge density of silanol groups on the pore wall allows a variety of functional groups to be incorporated for increasing selectivity [34]. A literature survey reveals that the application of silica embedded magnetite system has been aroused widespread in environmental analysis. For instance, octadecyl moieties derivatized $\mathrm{Fe}_{3} \mathrm{O}_{4}$ for polycyclic aromatic hydrocarbons from environmental samples [20] $\mathrm{Fe}_{3} \mathrm{O}_{4} @ \mathrm{SiO}_{2}-\mathrm{C} 18$ magnetic composite materials for extraction of organophosphorus pesticides [35], $\mathrm{Fe}_{3} \mathrm{O}_{4} @ \mathrm{SiO}_{2} @ \mathrm{PMMA}$ for enrichment peptides and proteins [36] and MCM-41 embedded $\mathrm{Fe}_{3} \mathrm{O}_{4}$ nanoparticles for the extraction and determination of selective antidepressant drugs in biological fluids [23].

There have been significant advances in magnetic nanoparticles applied as sorbents for magnetic solid phase extraction to the best of our knowledge, relatively few published works address the investigation of the potential use of mesoporous silica coated magnetic nanoparticles as a sorbent for magnetic solid phase extraction in organic pollutants agriculture crops. In 
view of the aforementioned, the main aim of this study was to investigate the synthesis of $\mathrm{Fe}_{3} \mathrm{O}_{4}-\mathrm{MCM}-41$ as an efficient sorbent for magnetic solid phase extraction (MSPE). Therefore, the extraction performance of sorbent was evaluated for MSPE to extract three OPPs (chlorpyrifos, diazinon and parathion methyl) in strawberry and grape samples prior to high performance liquid chromatography UV detection (HPLC-UV). To accomplish this purposed, the parameters affecting the extraction recoveries were investigated, and the related optimized values were obtained.

\section{- EXPERIMENTAL SECTION}

\section{Materials}

Analytical grade acetonitrile and methanol were obtained from Merck (Darmstadt, Germany), hydrochloric acid 37\%, ammonium hydroxide $\mathrm{NH}_{4} \mathrm{OH}$ $25 \%$, were provided from Sigma Aldrich (USA). Pesticide standard of chlorpyrifos, diazinon, and parathion methyl prepared in methanol were purchased from Sigma Aldrich (purity assay in range of $98-101 \%$ ). A stock solution $\left(1000 \mathrm{mg} \mathrm{L}^{-1}\right)$ of each pesticide was prepared in methanol, then a $100 \mathrm{mg} / \mathrm{L}$ intermediary standard mixture stock was achieved. For the synthesis of MCM-41 and $\mathrm{Fe}_{3} \mathrm{O}_{4}$-MCM-41, cetyltrimethylammonium bromide (CTABr) and Ludox colloidal (30\%) were purchased from Sigma-Aldrich. $\mathrm{FeCl}_{2} \cdot 4 \mathrm{H}_{2} \mathrm{O}$ and $\mathrm{FeCl}_{3}$ were obtained from Merck (Germany). Potassium dihydrogen phosphate $\left(\mathrm{KH}_{2} \mathrm{PO}_{4}\right)$, sodium hydroxide $(\mathrm{NaOH})$ and phosphoric acid were obtained from Merck (Darmstadt, Germany).

\section{Chromatographic Conditions}

The chromatographic analysis for pesticides was performed on a ZORBAX Eclipse $\mathrm{C}_{18}$ column $(5 \mu \mathrm{m} \times 2.1$ $\times 100 \mathrm{~mm}$ ) from Agilent Technologies, (USA), consisting of a quaternary pump and UV-Vis Detector. Analyte peaks were detected using Agilent UV-Vis detector at a selected wavelength of $210 \mathrm{~nm}$. The mobile phase consisted of acetonitrile and phosphate buffer $(\mathrm{pH} 4.5 ; 1 \mathrm{mM})$ at the ratio of $60: 40 \mathrm{v} / \mathrm{v}$. The flow rate was programmed at $0.2 \mathrm{~mL} \mathrm{~min}^{-1}$ and the injection $(0.2 \mu \mathrm{L})$ into the HPLC system was carried out manually using microsyringe Hamilton Company (California, USA).

\section{Procedure}

\section{Preparation of MCM-41 and $\mathrm{Fe}_{3} \mathrm{O}_{4}-\mathrm{MCM}-41$}

The MCM-41 was prepared according to the previous study [37-38] with minor modifications. Briefly, sodium silicate (solution A) was prepared by mixing $33.80 \mathrm{~mL}$ of Ludox (30\%) with $3.03 \mathrm{~g}$ sodium hydroxide $(\mathrm{NaOH})$ in $37.5 \mathrm{~mL}$ double distilled water at $80^{\circ} \mathrm{C}$ for $2 \mathrm{~h}$ with stirring. Another solution (solution B) was prepared separately by mixing $9.60 \mathrm{~g}$ of cetyltetraammonium bromide (CTABr) and $0.50 \mathrm{~g}$ of ammonium hydroxide $\left(\mathrm{NH}_{4} \mathrm{OH}\right)$ in $75.0 \mathrm{~mL}$ of distilled water, followed by stirring at $80^{\circ} \mathrm{C}$ until a clear solution was obtained. Both solutions, $\mathrm{A}$ and $\mathrm{B}$, were mixed in polypropylene bottle to give a gel with a composition of $6 \mathrm{SiO}_{2}:$ CTABr: $1.5 \mathrm{Na}_{2} \mathrm{O}: 0.15\left(\mathrm{NH}_{4}\right)_{2} \mathrm{O}: 250 \mathrm{H}_{2} \mathrm{O}$, followed by vigorous stirring. The resulting gel was kept in an air oven for crystallization at $100{ }^{\circ} \mathrm{C}$ for $24 \mathrm{~h}$. The gel then was cooled to room temperature, and the $\mathrm{pH}$ of the gel was adjusted approximately to 10.2 by adding 25 wt.\% acetic acid. The heating and $\mathrm{pH}$ adjustment were repeated twice. The solid product was filtered, washed, neutralized and dried overnight at $100{ }^{\circ} \mathrm{C}$. Finally, the solid product was calcined at $550{ }^{\circ} \mathrm{C}$ in the furnace.

$\mathrm{Fe}_{3} \mathrm{O}_{4}-\mathrm{MCM}-41$ (Fig. 1) was prepared by following the reported procedure with minor modification [39]. Briefly, $\mathrm{Fe}_{3} \mathrm{O}_{4}-\mathrm{MCM}-41$ was prepared by mixing $0.5 \mathrm{~g}$ of MCM-41 in $100 \mathrm{~mL}$ doubled distilled water and $1 \mathrm{mmol}$ $\mathrm{FeCl}_{2} \cdot 4 \mathrm{H}_{2} \mathrm{O}$ and $2 \mathrm{mmol} \mathrm{FeCl}_{3}$ were added to this solution. Then, the solution mixture was vigorously stirred

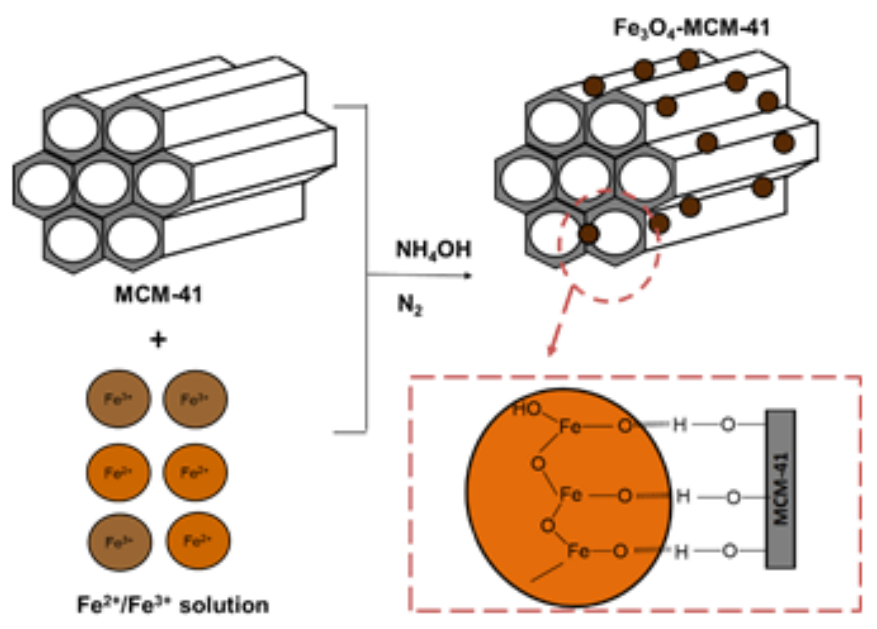

Fig 1. Synthesis route of $\mathrm{Fe}_{3} \mathrm{O}_{4}-\mathrm{MCM}-41$ [40] 
and degassed with nitrogen. During the stirring solution, $10 \mathrm{~mL}$ aqueous ammonium hydroxide solution was added dropwise. Once the solution became black, and it was continued stirring for another $1 \mathrm{~h}$. Finally, the solution was centrifuged with doubled distilled water until the $\mathrm{pH}$ becomes neutral. Then, the synthesized $\mathrm{Fe}_{3} \mathrm{O}_{4}-\mathrm{MCM}-41$ was dried in a vacuum desiccator at room temperature.

The characterization of synthesized MCM- 41 and $\mathrm{Fe}_{3} \mathrm{O}_{4}-\mathrm{MCM}-41$ was performed by Fourier transform infrared (FTIR), X-ray diffraction (XRD), field emission scanning electron microscopy (FESEM), and nitrogen adsorption-desorption isotherms. A Perkin Elmer 8300 Series KBr-Fourier transform infrared spectrometer (KBr-FTIR) was used $\mathrm{KBr}$ pellets method in the range from 4000 to $400 \mathrm{~cm}^{-1}$ for recording the FTIR spectra. Surface morphology and size of synthesized materials were studied using JEOL JEM-2300 field emission scanning electron microscopy (Tokyo, Japan) after coating the sample with a gold film, using a voltage $20 \mathrm{kV}$. Transmission electron microscopy (TEM) was performed using a JEM-2100F microscope $(200 \mathrm{kV})$. XRD analysis was carried out on (Rigaku) with CuKa radiation $(\lambda=$ $1.5406 \AA$, $30 \mathrm{Kv}, 30 \mathrm{~mA}$ ) to investigate the internal array of the composite. The specific surface area and averaged pore size of the prepared materials were determined using Brunauer-Emmett-Teller (BET) surface area analyzer (Belsorp-mini II, Japan). The sample was evacuated at $\left(300^{\circ} \mathrm{C}\right.$ and in nitrogen flow for $6 \mathrm{~h}$ ). The surface area was obtained from the linear of Brunauer-Emmett-Teller (BET) method using adsorption data in the relative pressure range from 0.05 to 0.2 . The pore size distribution was calculated from the adsorption branch of the isotherm using the Barrett-Joyner-Halenda (BJH) model.

\section{Real sample preparation}

Grape and strawberry were chosen as real model samples, and the sample preparation procedure was implemented based on the reported procedure [41]. Then, $1000 \mu \mathrm{L}$ of the standard solution of pesticides $\left(1 \mathrm{mg} \mathrm{L}^{-1}\right)$ in real samples was spiked into real samples ( $10 \mathrm{~g}$ of each) and kept at room temperature for $1 \mathrm{~h}$. Afterward, $10 \mathrm{~mL}$ of distilled water and $10 \mathrm{~mL}$ of methanol were added into it and was mashed using a laboratory mixer followed by homogenization using ultra-sonicator (4000 rpm) for
$5 \mathrm{~min}$. Finally, the solution was filtered using filter paper two times. The same procedure was conducted for unspiked samples without the addition of the standard solution of the pesticides. Finally, the filtered solutions (spiked and unspiked) were subjected to the proposed procedure.

\section{Extraction procedures for selected organophosphorus pesticides \\ Optimization of MSPE parameters. Different} parameters include types of extraction time, desorption solvent, desorption time, and sorbent dosage were optimized during the MSPE. Initially, $10 \mathrm{~mL}$ of sample volume, $50 \mathrm{mg}$ of sorbent, and $15 \mathrm{~min}$ extraction time were used for extraction of the selected chlorinated pesticides. The organophosphorus pesticides were eluted using $0.5 \mathrm{~mL}$ of different types of solvents.

Magnetic solid phase extraction (MSPE). The prepared of $\mathrm{Fe}_{3} \mathrm{O}_{4}$-MCM-41 composite was studied as MSPE sorbent for the enhanced preconcentration of the targeted pesticides from fruit samples [42]. Briefly, an optimum weight of the sorbent $\mathrm{Fe}_{3} \mathrm{O}_{4}-\mathrm{MCM}-41$ (50 mg) was added into $10 \mathrm{~mL}$ of treated samples spiked with known variable amounts of selected pesticides. The mixture was shaken $(250 \mathrm{rpm})$ for $15 \mathrm{~min}$ at room temperature by orbital shaker to achieve a homogenous dispersion solution. With the aid of an external magnet, the sample solution was be removed, and the trapped analytes were eluted with $500 \mu \mathrm{L}$ of acetone under ultrasonication for $5 \mathrm{~min}$. Finally, the magnet was again placed to the vial, and the eluate was evaporated under the mild nitrogen stream, and the resultant residue was reconstituted with $0.1 \mathrm{~mL}$ acetone. An aliquot $(2 \mu \mathrm{L})$ of final extract sample was injected into the HPLC/UV. Simplified schematic of the analytical procedure of MSPE is illustrated in Fig. 2.

\section{MCM-41-DSPE procedure}

A synthesized MCM-41 was optimized with important extraction parameters such as type of solvent, desorption time, sorbent dosage, extraction time. Acetone, acetonitrile, methanol, and ethyl acetate with $0.5 \mathrm{~mL}$ was used to optimize the effect of the solvent on MCM-41-DSPE. Comparatively, high extraction efficiency was achieved using $0.5 \mathrm{~mL}$ acetone at different 


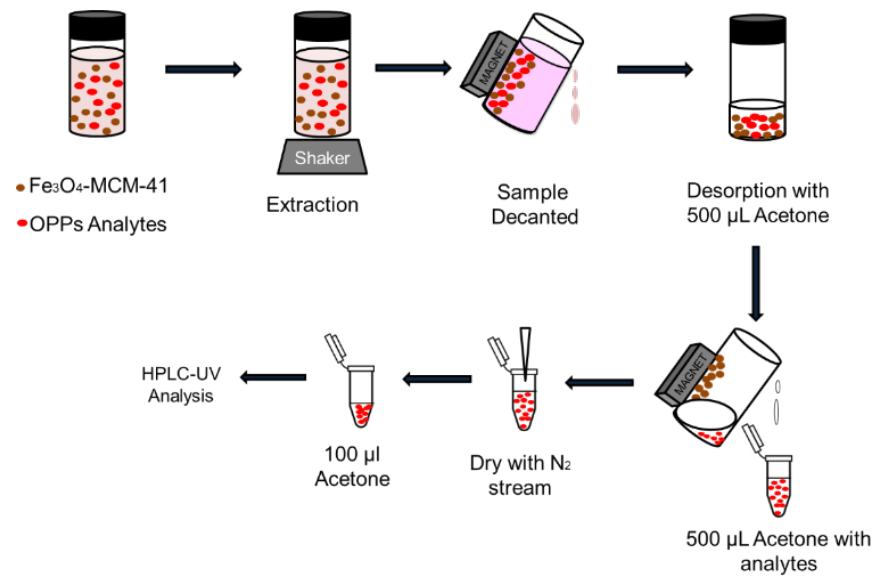

Fig 2. Schematic illustration of magnetic solid phase extraction using $\mathrm{Fe}_{3} \mathrm{O}_{4}-\mathrm{MCM}-41$ sorbent

desorption time (1 to $10 \mathrm{~min}$ ). On the basis of the results, $0.5 \mathrm{~mL}$ of acetone at $5 \mathrm{~min}$ desorption time was selected as optimized desorption time. In order to improve the preconcentration factor, the sorbent dosage was also optimized (30 to $100 \mathrm{mg}$ ). The maximum extraction efficiency was obtained with $50 \mathrm{mg}$ of sorbent dosage and thus was selected as the optimized sorbent dosage. The best result was achieved at 15 min extraction time.

\section{- RESULTS AND DISCUSSION}

\section{Characterization FTIR Analysis}

FTIR analyses were employed to ascertain functional groups performed in $\mathrm{Fe}_{3} \mathrm{O}_{4}, \mathrm{MCM}-41$, and $\mathrm{Fe}_{3} \mathrm{O}_{4}-\mathrm{MCM}-41$ sorbents. Major adsorption bands shown in prepared sorbents were summarized in Table 1. As shown in Fig. 3, a large, broad band in all samples between 3450 and $3330 \mathrm{~cm}^{-1}$ corresponds $\mathrm{O}-\mathrm{H}$ stretching vibration mode of silanol groups and the band at $1639 \mathrm{~cm}^{-1}$ is assigned to bending mode of $\mathrm{O}-\mathrm{H}$ and the adsorbed water [42-43]. The typical adsorption peaks at 1077, 800 and $460 \mathrm{~cm}^{-1}$, which ascribed to the presence of asymmetric $\mathrm{Si}-\mathrm{O}-\mathrm{Si}$ stretching, symmetric $\mathrm{Si}-\mathrm{O}-\mathrm{Si}$ stretching and $\mathrm{Si}-\mathrm{O}-\mathrm{Si}$ vibration, appear in the infrared spectra of MCM-41 and $\mathrm{Fe}_{3} \mathrm{O}_{4}-\mathrm{MCM}-41$, respectively [45-47]. Furthermore, the adsorption peak shown in pristine $\mathrm{Fe}_{3} \mathrm{O}_{4}$ at $599 \mathrm{~cm}^{-1}$ (Fig. 3(b)) indicated the $\mathrm{Fe}-\mathrm{O}$ stretching [45-46]. The $\mathrm{Fe}_{3} \mathrm{O}_{4}$-MCM-41 particles show characteristics peaks at 464 and $1636 \mathrm{~cm}^{-1}$, which slightly decreased with the appearance of the $\mathrm{Fe}-\mathrm{O}-\mathrm{Si}$ covalent bonding due to $\mathrm{OH}$ condensation [44]. Consequently, changes of some characteristic peaks confirmed the $\mathrm{Fe}_{3} \mathrm{O}_{4}$ nanoparticles were successfully anchored on the surface of MCM-41.

\section{X-ray Diffraction}

XRD patterns of MCM-41 and $\mathrm{Fe}_{3} \mathrm{O}_{4}-\mathrm{MCM}-41$ are shown in Fig. 4(a) and 4(b), respectively. The diffractogram of MCM-41 exhibited Bragg peaks at low

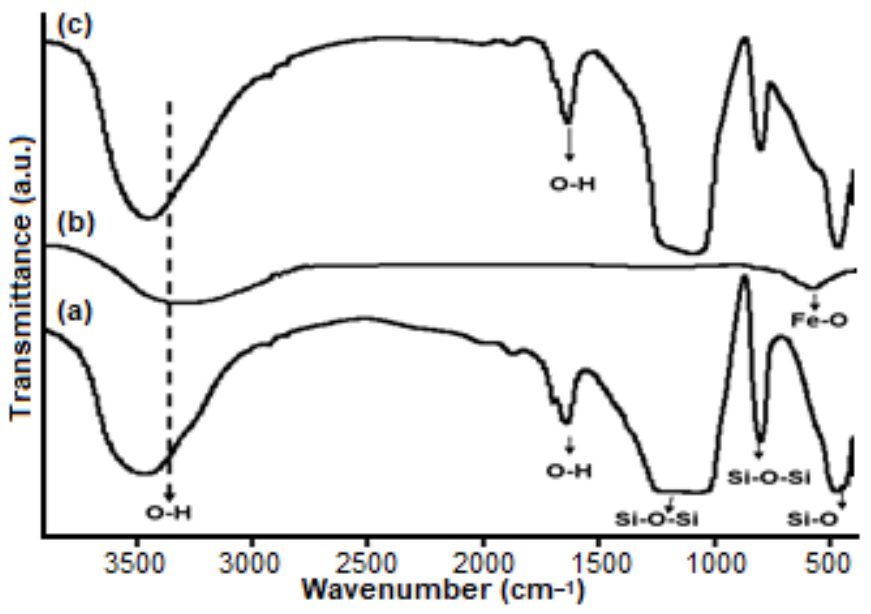

Fig 3. FTIR spectra of (a) MCM-41, (b) $\mathrm{Fe}_{3} \mathrm{O}_{4}$ and (c) $\mathrm{Fe}_{3} \mathrm{O}_{4}-\mathrm{MCM}-41$

Table 1. Comparison of FTIR absorption bands of MCM-41 and $\mathrm{Fe}_{3} \mathrm{O}_{4}-\mathrm{MCM}-41$

\begin{tabular}{lccc}
\hline \multirow{2}{*}{ Adsorption stretching bands } & \multicolumn{3}{c}{ Wavelength $\left(\mathrm{cm}^{-1}\right)$} \\
\cline { 2 - 4 } & $\mathrm{MCM}-41$ & $\mathrm{Fe}_{3} \mathrm{O}_{4}$ & $\mathrm{Fe}_{3} \mathrm{O}_{4}-\mathrm{MCM}-41$ \\
\hline O-H stretching & 3453 & 3330 & 3450 \\
O-H bending & 1639 & - & 1636 \\
Asymmetric Si-O-Si & 1077 & - & 1096 \\
Symmetric Si-O-Si & 800 & - & 798 \\
$\mathrm{Si}-\mathrm{O}-\mathrm{Si}$ & 459 & - & 463 \\
$\mathrm{Fe}-\mathrm{O}$ & - & 599 & - \\
\hline
\end{tabular}


angles between $0.967-1.865^{\circ}$, indexed as (100), (110) and (200) in the hexagonal system (Fig. 4(a)). These peaks are typical of these materials and arise from the quasiregular arrangement of the mesopores in the bulk material [50]. However, the obtained XRD pattern appeared only one broad peak at $2 \theta$ of $0.967^{\circ}$ due to (100), and two extremely weak peaks between 1.203 and $1.865^{\circ}$ due to (110) and (200) planes, being indicative of a material which does not exhibit long-range mesopores ordering [51]. Meanwhile, the broad diffraction peaks of $2 \theta$ at $20-30^{\circ}$ shown in the angle XRD pattern of $\mathrm{Fe}_{3} \mathrm{O}_{4}-\mathrm{MCM}-41$ are the characteristics from the amorphous silica template (Fig. 4(b). The diffraction peaks appeared at $2 \theta$ of 35.7, 43.3, 56.4 , and $63.1^{\circ}$ were assigned to (311), (400), (511) and (440) reflections, respectively, which are indexed to the spinel structure of pure stoichiometric $\mathrm{Fe}_{3} \mathrm{O}_{4}$ (JCPDS Card No. 19-0629) [39]. The characteristic peaks of the existence of magnetite particles in $\mathrm{Fe}_{3} \mathrm{O}_{4}-\mathrm{MCM}-41$ exhibited the same textural property as MCM-41, which confirmed that mesoporosity was preserved after synthesis of $\mathrm{Fe}_{3} \mathrm{O}_{4}$ nanoparticles.

\section{Morphology Property}

The surface morphology of synthesized of MCM41 and $\mathrm{Fe}_{3} \mathrm{O}_{4}-\mathrm{MCM}-41$ were analyzed via field emission scanning electron microscopy (FESEM) and transmission electron microscopy (TEM). The micrographs are illustrated in Fig. 5 and 6. The FESEM micrograph of

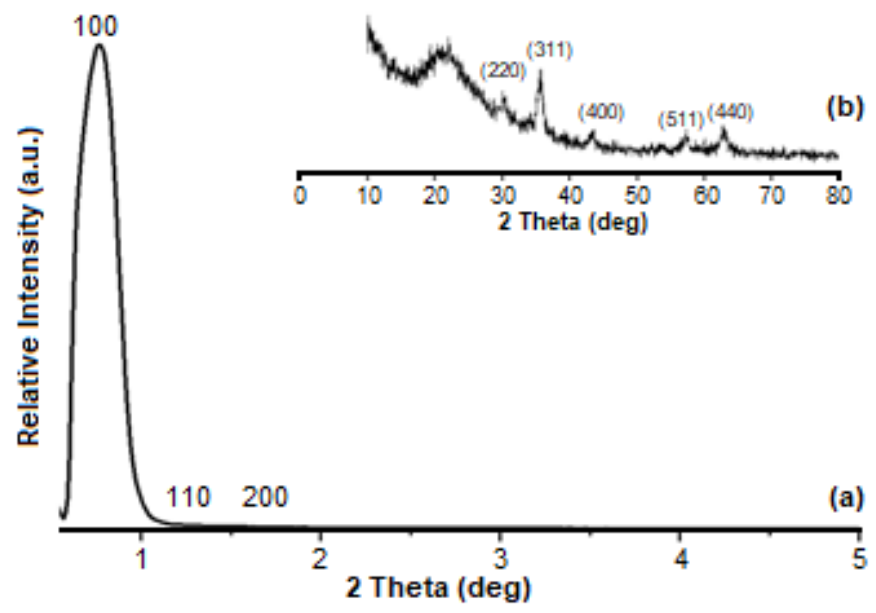

Fig 4. XRD patterns of (a) MCM-41 (b) $\mathrm{Fe}_{3} \mathrm{O}_{4}-\mathrm{MCM}-41$ composite

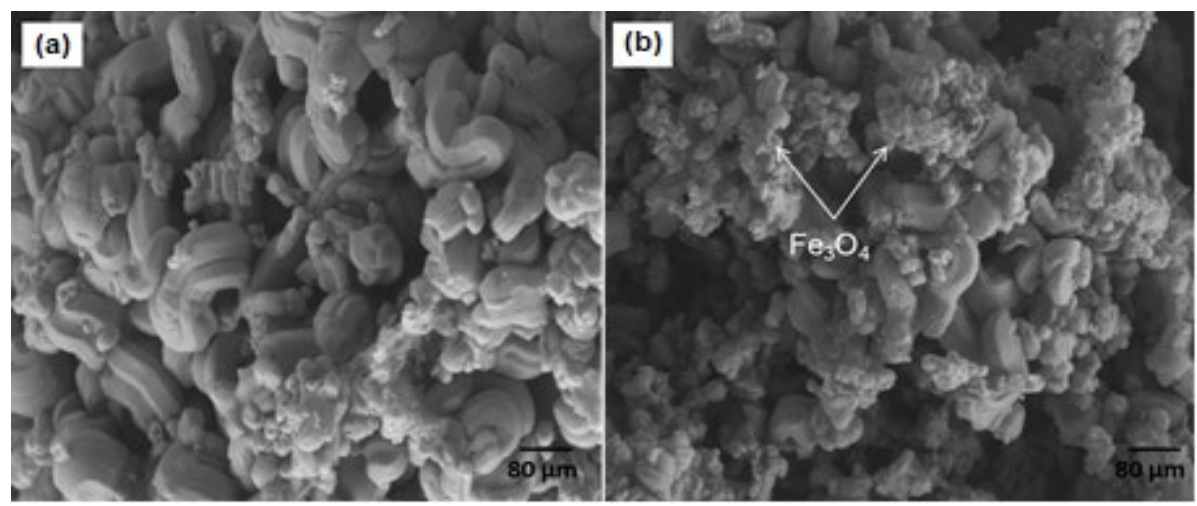

Fig 5. Micrograph image of (a) MCM-41 and (b) $\mathrm{Fe}_{3} \mathrm{O}_{4}-\mathrm{MCM}-41$ observed at $5 \mathrm{~K}$ magnification
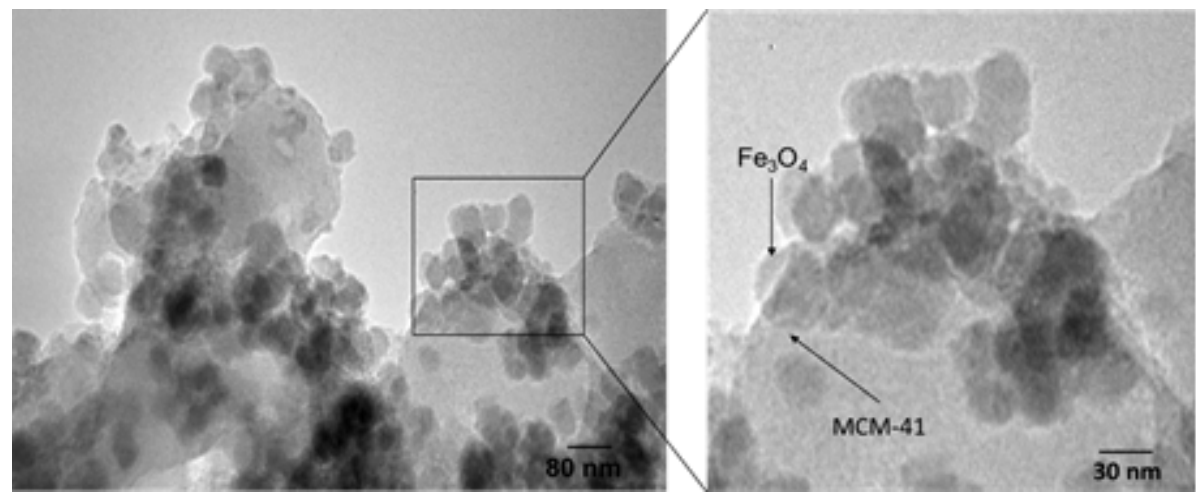

Fig 6. TEM images of $\mathrm{Fe}_{3} \mathrm{O}_{4}-\mathrm{MCM}-41$ 
MCM-41 in Fig. 5(a), showed loosely agglomerated particles with a rod-like shape, with uniform pore size about $3.83 \mathrm{~nm}$, which is a good agreement with narrow size distribution $(\mathrm{BJH})$ determined by nitrogen adsorption-desorption measurement [52]. After dispersing with $\mathrm{Fe}_{3} \mathrm{O}_{4}$, Fig. 5(b) clearly shows that the distribution of magnetite particles on the surface of MCM-41 unnoticeable coating. Besides, the particle sizes are difficult to measure due to the agglomeration of magnetite particles on the surface of MCM-41. In order to indicate the iron oxide nanoparticles on the surface of mesoporous silica, a detailed TEM analysis was performed. TEM images are shown in Fig. 6, the iron oxide nanoparticles dispersed and appeared as dark dotlike objects on the surface of mesoporous silica with an average diameter approximately about $13 \mathrm{~nm}$. Besides some particles could be seen in partially aggregated due to the existence of magnetic interaction between particle [27]. Thus, the TEM analysis gives evidence that the ordered mesoporous structure is maintained after dispersing.

\section{Nitrogen Desorption Adsorption Isotherm}

The isotherm of nitrogen adsorption-desorption and the corresponding pore size distribution curve of various prepared samples are presented in Fig. 7. Apparently, all samples exhibit a typical type IV physisorption curves which indicate the pattern of

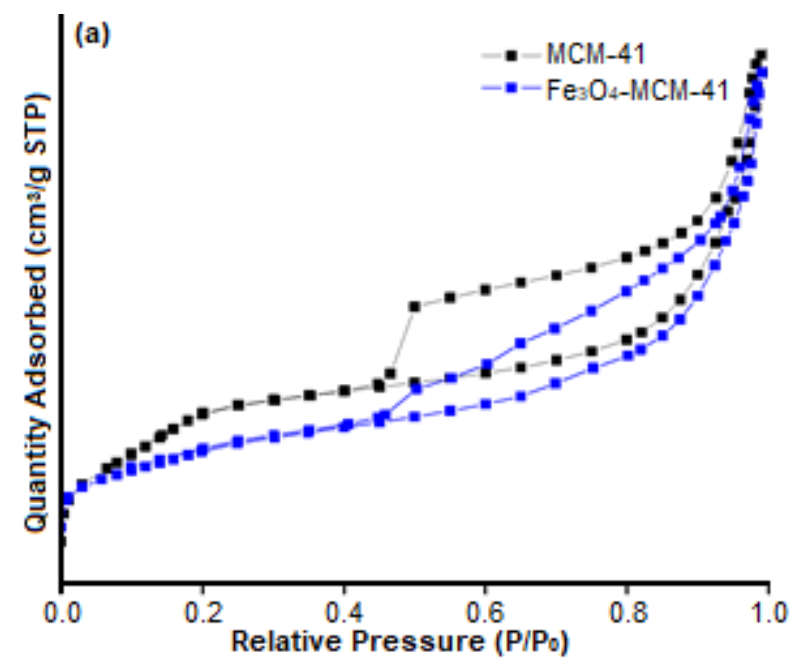

mesopores materials $(2-50 \mathrm{~nm})$ according to the classifications of the IUPAC (Fig. 7(a)). The samples also display clear $\mathrm{H} 1$ type hysteresis loop with rapid in nitrogen uptake $\mathrm{p} / \mathrm{p}_{0}=(0.4-1.0)$, which is due to monolayer adsorption of nitrogen to the walls of the mesopores. Furthermore, the samples also demonstrated a narrow pore size distribution by the $\mathrm{BJH}$ method, as shown by the inset in Fig. 7(b). The pore size distribution centered near $(3.83 \mathrm{~nm})$ for MCM-41 and $\mathrm{Fe}_{3} \mathrm{O}_{4}-\mathrm{MCM}$ $41(3.39 \mathrm{~nm})$, respectively, suggest that the pore size is predominantly composed of mesopores and concentrated in the small size range. $\mathrm{Fe}_{3} \mathrm{O}_{4}-\mathrm{MCM}-41$ composite contributes a small pore size compared to the pure mesoporous due to the magnetite particles $\left(\mathrm{Fe}_{3} \mathrm{O}_{4}\right)$ occupy on the mesopore free space intrachannels of MCM-41 partially [40]. This makes this composite a promising candidate for the incorporation and subsequent analysis under appropriate conditions.

The effective adsorption functional groups in the MCM-41 and $\mathrm{Fe}_{3} \mathrm{O}_{4}-\mathrm{MCM}-41$ pores is studied by the expressive of surface area, size, and pore volume, as presented in Table 1. A sensible difference was observed for the BET specific surface of MCM-41 $\left(436 \mathrm{~m}^{2} \mathrm{~g}^{-1}\right)$ and $\mathrm{Fe}_{3} \mathrm{O}_{4}-\mathrm{MCM}-41\left(293 \mathrm{~m}^{2} / \mathrm{g}\right)$, respectively. From the results obtained, it can be concluded that the pore size of distribution in this study can be varied within $3.83 \mathrm{~nm}$ to $13 \mathrm{~nm}$ due to the irregular pore and surface area of prepared materials. However, this pore size is sufficient

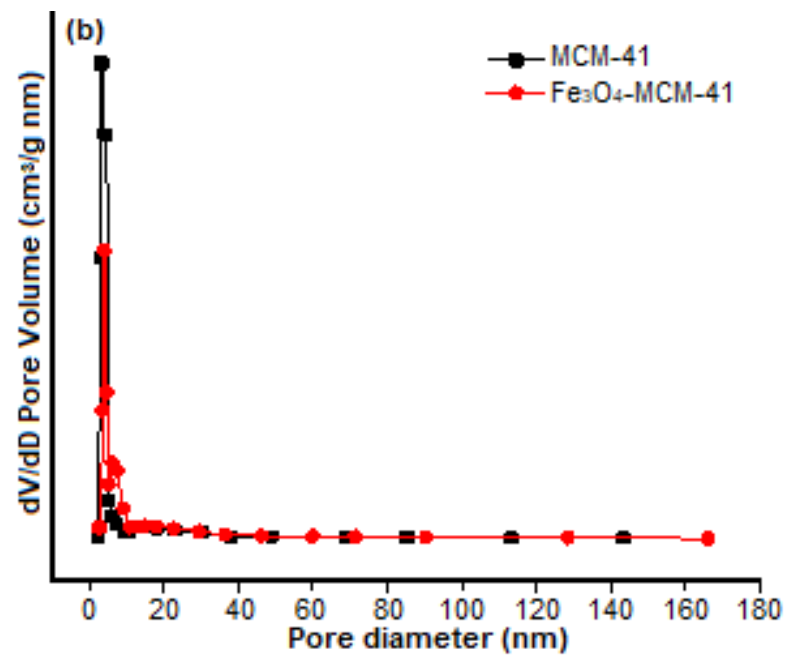

Fig 7. (a) $\mathrm{N}_{2}$ adsorption isotherms, (b) Pore size distribution of pure MCM-41 and $\mathrm{Fe}_{3} \mathrm{O}_{4}-\mathrm{MCM}-41$ composite 
Table 2. $\mathrm{N}_{2}$ adsorption results

\begin{tabular}{|c|c|c|c|}
\hline Sample & $\mathrm{S}_{\mathrm{BET}}\left(\mathrm{m}^{2} \mathrm{~g}^{-1}\right)$ & $\mathrm{D}_{\mathrm{p}}(\mathrm{nm})$ & $V_{p}\left(\mathrm{~cm}^{3} \mathrm{~g}^{-1}\right)$ \\
\hline MCM-41 & 436 & 11.27 & 0.533 \\
\hline $\mathrm{Fe}_{3} \mathrm{O}_{4}-\mathrm{MCM}-41$ & 293 & 10.70 & 0.465 \\
\hline
\end{tabular}

enough for the sorption of targeted pesticides. Details results for sorption studies will be discussed in subtopic analytical performance.

\section{Optimization of MSPE Procedure}

A batch-wise MSPE was investigated to assess the extraction efficiency of the synthesized $\mathrm{Fe}_{3} \mathrm{O}_{4}$-MCM-41 sorbent for the selected organophosphorus pesticides. In order to optimize extraction conditions, several main parameters including desorption solvent, extraction time, desorption time and sorbent dosage were studied in one variable at a time (OVAT), which ensures the variable responsible for any effect observed is clearly identified.

\section{Effect of extraction time}

As an equilibrium extraction step is concerned, a parameter plays imperative rules on the extraction efficiency. The effect of extraction time on the extraction efficiency of OPPs using $\mathrm{Fe}_{3} \mathrm{O}_{4}$-MCM-41 was performed to achieve the highest sensitivity and recovery. Extraction was investigated at different shaking time from 5 to $20 \mathrm{~min}$. The extraction efficiency depends on the mass transfer between $\mathrm{Fe}_{3} \mathrm{O}_{4}-\mathrm{MCM}-41$ and analytes in the sample solution. As illustrated in Fig. 8(a), there was a rapid increase in extraction efficiency of all analytes when the extraction time was prolonged from 5 to $15 \mathrm{~min}$, and the peak areas remained nearly constant or decreased when the extraction time was further increased to $20 \mathrm{~min}$. This phenomenon might be due to the back-extraction of analytes from the adsorbent into the sample solution [53]. Thus, $15 \mathrm{~min}$ was selected as the optimum extraction time for subsequent extractions.
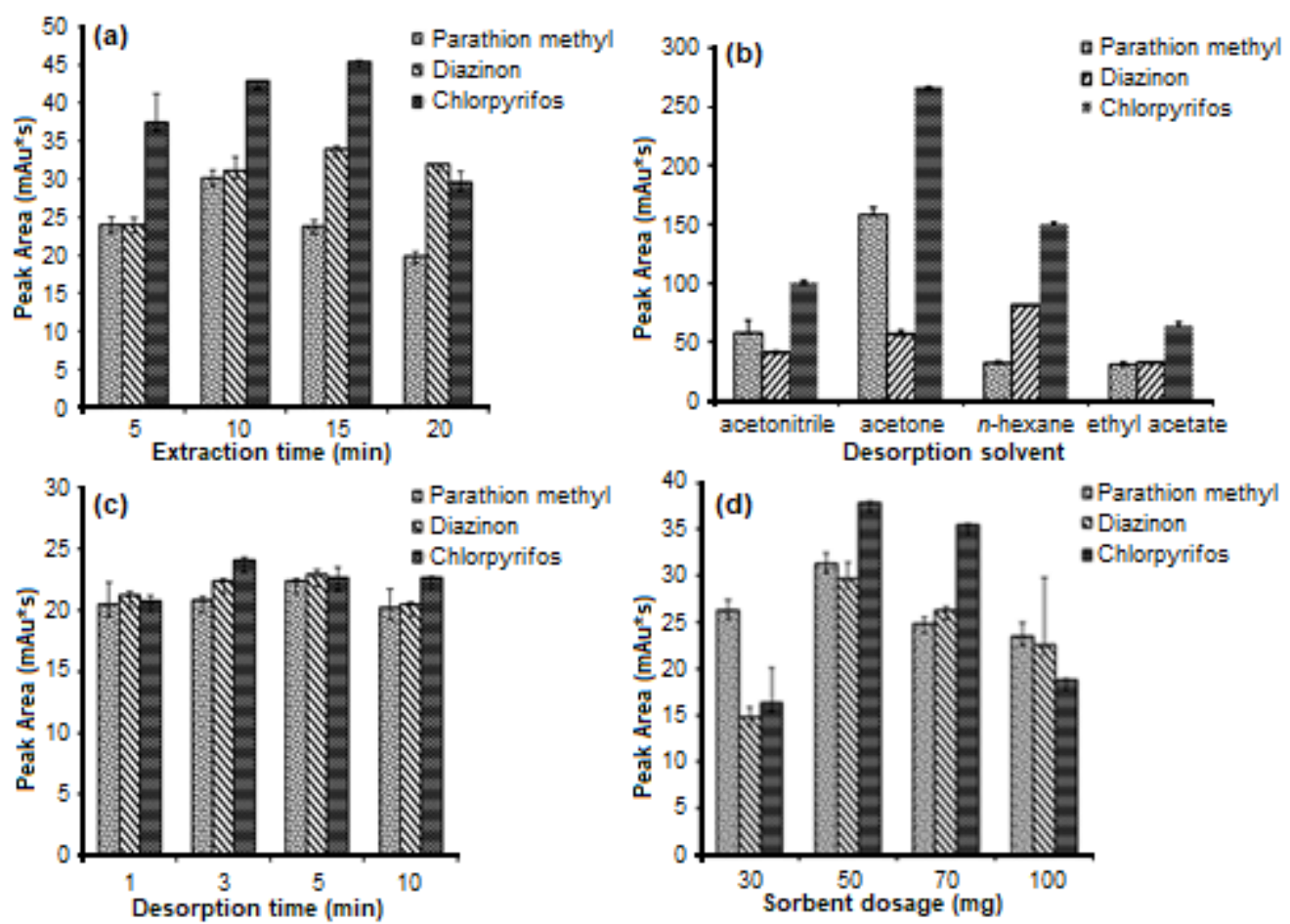

Fig 8. Effect of (a) extraction time, (b) desorption solvents, (c) desorption time and (d) sorbent dosage on OPPs pesticide extraction efficiency 


\section{Effect of desorption solvent}

The selection of an appropriate desorption solvent plays a vital role in the MSPE process to ensure high recovery and sensitivity on method performance [11]. In general, the selection of desorption solvent, the polarity of solvents, the solubility of analytes relies on its compatibility of the analytical instrument should be considered. Due to the selected of OPPs relatively mid-polar and they were adsorbed strongly on $\mathrm{Fe}_{3} \mathrm{O}_{4}-\mathrm{MCM}-41$ surface, thus only polar solvent can disrupt the interaction and desorbed the analytes. Hence, four organic solvents of different polarity, namely, acetonitrile, acetone, ethyl acetate, and hexane, respectively, were performed to elute the adsorbed analyte from the magnetic $\mathrm{Fe}_{3} \mathrm{O}_{4}-\mathrm{MCM}-41$ sorbent. These solvents have different polarities, with ethyl acetate being the most polar solvent and $n$-hexane being the most nonpolar solvent. It is obviously shown in Fig. 8(b) that the $n$ hexane provided good response and satisfactory efficiency towards non-polar chlorpyrifos and diazinon.

Particularly, the $\mathrm{Fe}_{3} \mathrm{O}_{4}$-MCM-41 could not be dispersed well in $n$-hexane, which impeded the effective desorption of analytes from sorbent, but $n$-hexane is a non-polar solvent, and it provide hydrophobic interactions with selected non-polar OPPs, which similar in chemical characteristics. Otherwise, the acetone gave the highest response towards polar parathion methyl and as well as satisfactory efficiency was also obtained for the non-polar OPPs due to its highest desorption ability, and it is the least viscous solvent compared to the other three solvents except for diazinon whose response was lower than parathion methyl and chlorpyrifos. Hence, $500 \mu \mathrm{L}$ of acetone was selected for the desorption of polar and nonpolar compounds throughout the entire study as a desorption solvent.

\section{Effect of desorption time}

Desorption time is regarded as the time that is required to desorb all the analytes from the sorbent. In order to study the effect of desorption time (Fig. 8(c)), the process was performed with the aid of an ultrasonicator at different durations in the range $1 \mathrm{~min}$ to $10 \mathrm{~min}$. It can be observed that the peak area increased with desorption time to reach a maximum at $5 \mathrm{~min}$. Beyond this point
(10 min), no significant increase peak area was observed due to the analytes being re-adsorbed by the sorbent [54]. Therefore, $5 \mathrm{~min}$ was adequate and acceptable to elute all the absorbed analytes fully.

\section{Effect of sorbent dosage}

The optimization of the mass of the sorbent is one of critical condition that provides a sufficient capacity to retain both the analyte and any contaminants that may be also be retained during the loading procedure [17]. In order to achieve the highest extraction recovery, the effect of sorbent dosage was assessed by changing the mass of sorbent in the range of 30 to $100 \mathrm{mg}$ to extract the selected OPPs pesticides (Fig. 8(d)). This graph clarified that the peak area ratio of the extracted OPPs remarkably increased up to $50 \mathrm{mg}$ of the sorbent. However, when $70 \mathrm{mg}$ of sorbent was used, no additional enhancement of the peak area was observed. The decrease in response could be due to the saturation of the active site on the adsorbent that has been exceeded. Thus, $50 \mathrm{mg}$ of sorbent was adopted for subsequent analysis.

\section{Extraction Performance of $\mathrm{Fe}_{3} \mathrm{O}_{4}, \mathrm{MCM}-41$, and $\mathrm{Fe}_{3} \mathrm{O}_{4}-\mathrm{MCM}-41$}

Comparative studies were performed in order to compare the extraction performance of the newly synthesized of $\mathrm{Fe}_{3} \mathrm{O}_{4}, \mathrm{MCM}-41$ and $\mathrm{Fe}_{3} \mathrm{O}_{4}-\mathrm{MCM}-41$ sorbents for pre-concentration of four pesticides of different polarity organophosphorus pesticides (chlorpyrifos, diazinon, and parathion-methyl). Fig. 9 illustrates that the $\mathrm{Fe}_{3} \mathrm{O}_{4}$ showed unsatisfactory $(<10 \%)$ towards the all selected OPPs studied as evidence by the extraction recoveries observed. However, when $\mathrm{Fe}_{3} \mathrm{O}_{4}{ }^{-}$ MCM-41 particles were utilized as a sorbent, relatively higher extraction recoveries ( $>70 \%$ ) of OPPs pesticides were obtained [23]. The capability of $\mathrm{Fe}_{3} \mathrm{O}_{4}-\mathrm{MCM}-41$ exhibited the highest extraction recoveries due to the analyte was adsorbed on the active site of MCM-41, and this possibility might be due to the hydrogen bonding interaction between the silanol groups of MCM-41 with different anionic sites $(\mathrm{O}, \mathrm{N}, \mathrm{S}$, and $\mathrm{Cl})$ of the selected OPPs [55]. 


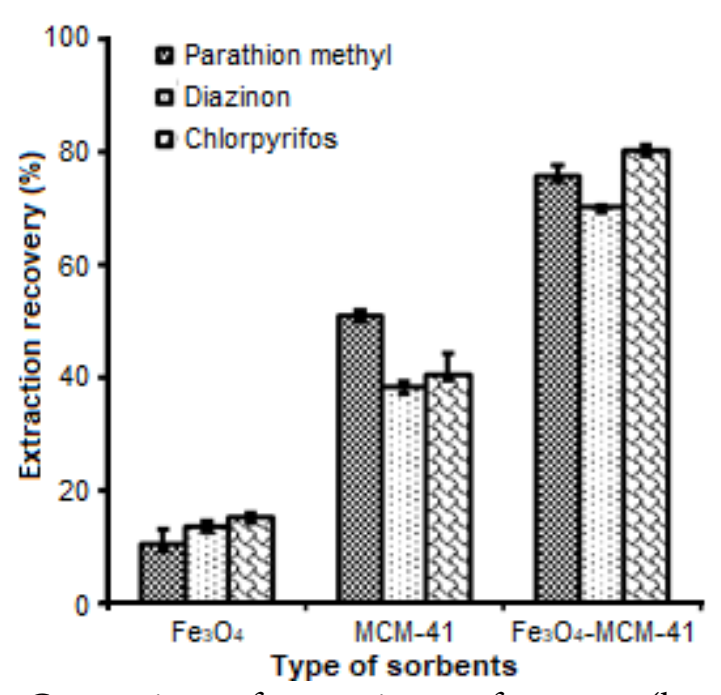

Fig 9. Comparison of extraction performance (based on extraction recoveries) of three different sorbents for the OPPs pre-concentration. Condition for extractions: sample volume $10 \mathrm{~mL}$, mass of sorbent $50 \mathrm{mg}$, concentration of analytes $1 \mathrm{mg} \mathrm{L}^{-1}$, extraction time $15 \mathrm{~min}$, desorption time $3 \mathrm{~min}$ and $0.5 \mathrm{~mL}$ acetone as desorption solvent

\section{Analytical Performance}

Quantitative analysis of MSPE method based on $\mathrm{Fe}_{3} \mathrm{O}_{4}$-MCM-41 as sorbent was validated under the optimized conditions using different analytical parameters such as linearity, the limit of detection (LOD), the limit of quantification (LOQ), precision and accuracy. Matrix match calibration was performed by spiking different concentrations of the selected pesticides into the strawberry and grape samples. The linearity of the MSPE technique for OPPs pesticides using MCM-41 and $\mathrm{Fe}_{3} \mathrm{O}_{4}-\mathrm{MCM}-41$ was performed in the range from $0.1-5.00 \mathrm{mg} \mathrm{L}^{-1}$ for strawberry and grape samples. Good linearity with a high value of the coefficient of determination $\left(\mathrm{R}^{2}\right)$ was higher than 0.9900 in the linear range (Table 3). The LOD $(\mathrm{S} / \mathrm{N}=3)$ obtained for all pesticides in the range $0.02-0.15 \mathrm{mg} \mathrm{L}^{-1}$ and the LOQ (10 $\times \mathrm{S} / \mathrm{N}$ ) in the range $0.06-0.40 \mathrm{mg} \mathrm{L}^{-1}$. However, the obtained LOD for $\mathrm{Fe}_{3} \mathrm{O}_{4}$-MCM-41 is appreciably lower as compared to the MCM-41. Besides, LOD obtained for $\mathrm{Fe}_{3} \mathrm{O}_{4}-\mathrm{MCM}-41$ was well below the maximum residue limits (MRLs) real-life range of grape and strawberry (10 $\left.\mathrm{mg} \mathrm{L}^{-1}\right)$ set by EU for each pesticide. Thus, the proposed MSPE method based on $\mathrm{Fe}_{3} \mathrm{O}_{4}-\mathrm{MCM}-41$ is highly efficient for the determination of these selected pesticides in fruit samples.

Repeatability and reproducibility of the proposed MSPE method were investigated using intraday and interday measurements. Relative standard deviation (\%RSD) were assessed at low and high concentrations (0.1-5.0 $\mathrm{mg} \mathrm{L}^{-1}$ ) with triplicate analyses on the same day and over three different days $(\mathrm{n}=3)$ using fruits samples, respectively. Acceptable results based on RSD\% were obtained in the range from 1.0 to $6.0 \%(\mathrm{n}=3)$ and 1.0 to $7.0 \%(\mathrm{n}=3)$ for intraday and interday precision respectively (Table 4).

Table 3. Statistical results of MSPE method for selected pesticides, including linear range, correlation coefficients $\left(\mathrm{R}^{2}\right)$, the limit of detection (LOD), the limit of quantification (LOQ) of MCM-41 and $\mathrm{Fe}_{3} \mathrm{O}_{4}-\mathrm{MCM}-41$ of OPPs spiked in fruits samples $(\mathrm{n}=3)$

\begin{tabular}{lccccccccc}
\hline & \multicolumn{3}{c}{$\mathrm{Fe}_{3} \mathrm{O}_{4}-\mathrm{MCM}-41$} & \multicolumn{3}{c}{ MCM-41 } \\
\cline { 2 - 9 } & $\begin{array}{c}\text { Linearity } \\
\left(\mathrm{mg} \mathrm{L}^{-1}\right)\end{array}$ & $\begin{array}{c}\mathrm{LOD} \\
\left(\mathrm{mg} \mathrm{L}^{-1}\right)\end{array}$ & $\begin{array}{c}\text { LOQ } \\
\left(\mathrm{mg} \mathrm{L}^{-1}\right)\end{array}$ & $\mathrm{R}^{2}$ & $\begin{array}{c}\text { Linearity } \\
\left(\mathrm{mg} \mathrm{L}^{-1}\right)\end{array}$ & $\begin{array}{c}\text { LOD } \\
\left(\mathrm{mg} \mathrm{L}^{-1}\right)\end{array}$ & $\begin{array}{c}\text { LOQ } \\
\left(\mathrm{mg} \mathrm{L}^{-1}\right)\end{array}$ & $\mathrm{R}^{2}$ \\
\hline Strawberry & & & & & & & & \\
Chlorpyrifos & $0.1-5.00$ & 0.02 & 0.06 & 0.9955 & $0.1-5.00$ & 0.12 & 0.38 & 0.9942 \\
Diazinon & $0.1-5.00$ & 0.12 & 0.39 & 0.9935 & $0.1-5.00$ & 0.15 & 0.40 & 0.9950 \\
Parathion methyl & $0.1-5.00$ & 0.12 & 0.38 & 0.9940 & $0.1-5.00$ & 0.10 & 0.22 & 0.9912 \\
Grapes & & & & & & & 0.11 & 0.22 & 0.9945 \\
Chlorpyrifos & $0.1-5.00$ & 0.04 & 0.13 & 0.9966 & $0.1-5.00$ & 0.13 & 0.36 & 0.9971 \\
Diazinon & $0.1-5.00$ & 0.04 & 0.12 & 0.9960 & $0.1-5.00$ & 0.13 & 0.34 & 0.9960 \\
Parathion methyl & $0.1-5.00$ & 0.06 & 0.19 & 0.9980 & $0.1-5.00$ & 0.14 & 0.34 \\
\hline
\end{tabular}


Table 4. Study of repeatability and reproducibility of the MSPE method based on intraday and interday precisions

\begin{tabular}{|c|c|c|c|c|}
\hline \multirow{4}{*}{ Analyte } & \multicolumn{4}{|c|}{ MSPE precision } \\
\hline & \multicolumn{2}{|c|}{ Intraday \%RSD $(\mathrm{n}=3)$} & \multicolumn{2}{|c|}{ Interday \%RSD $(\mathrm{n}=3)$} \\
\hline & \multicolumn{4}{|c|}{ Spiked in fruits samples $\left(\mathrm{mg} \mathrm{L}^{-1}\right)$} \\
\hline & 0.1 & 5.00 & 0.1 & 5.00 \\
\hline \multicolumn{5}{|l|}{ Grapes } \\
\hline Chlorpyrifos & $74.9(3.2)$ & $125.2(1.2)$ & $95.8(6.4)$ & $100.89(0.3)$ \\
\hline Diazinon & $75.9(2.7)$ & $95.2(4.3)$ & $70.7(1.4)$ & $122.08(4.5)$ \\
\hline Parathion methyl & $75.5(1.9)$ & $92.9(4.1)$ & $76.1(2.1)$ & $114.5(1.2)$ \\
\hline \multicolumn{5}{|l|}{ Strawberry } \\
\hline Chlorpyrifos & $73.8(4.6)$ & $107.7(0.8)$ & $72.6(5.8)$ & $100.63(1.1)$ \\
\hline Diazinon & $74.50(5.8)$ & $69.94(3.8)$ & $92.6(6.4)$ & $88.48(4.2)$ \\
\hline Parathion methyl & $79.4(4.3)$ & $108.1(4.4)$ & $70.9(6.6)$ & $73.76(3.4)$ \\
\hline
\end{tabular}

Reusability of the adsorbent was carried out by evaluating the extraction performance of $\mathrm{Fe}_{3} \mathrm{O}_{4}-\mathrm{MCM}-41$ for different extraction-desorption cycles. In order to investigate the regeneration of the sorbent, the used of sorbent was washed subsequently with acetone respectively after each extraction, and then the dried sorbent was used in the subsequent analysis. The result indicates that $\mathrm{Fe}_{3} \mathrm{O}_{4}-\mathrm{MCM}-41$ could be used repeatedly at least three times without a significant decrease in extraction recoveries (> 90\%) and its magnetic property. These results show the adsorbent is stable for repeated used, which is favorable for MSPE based method.
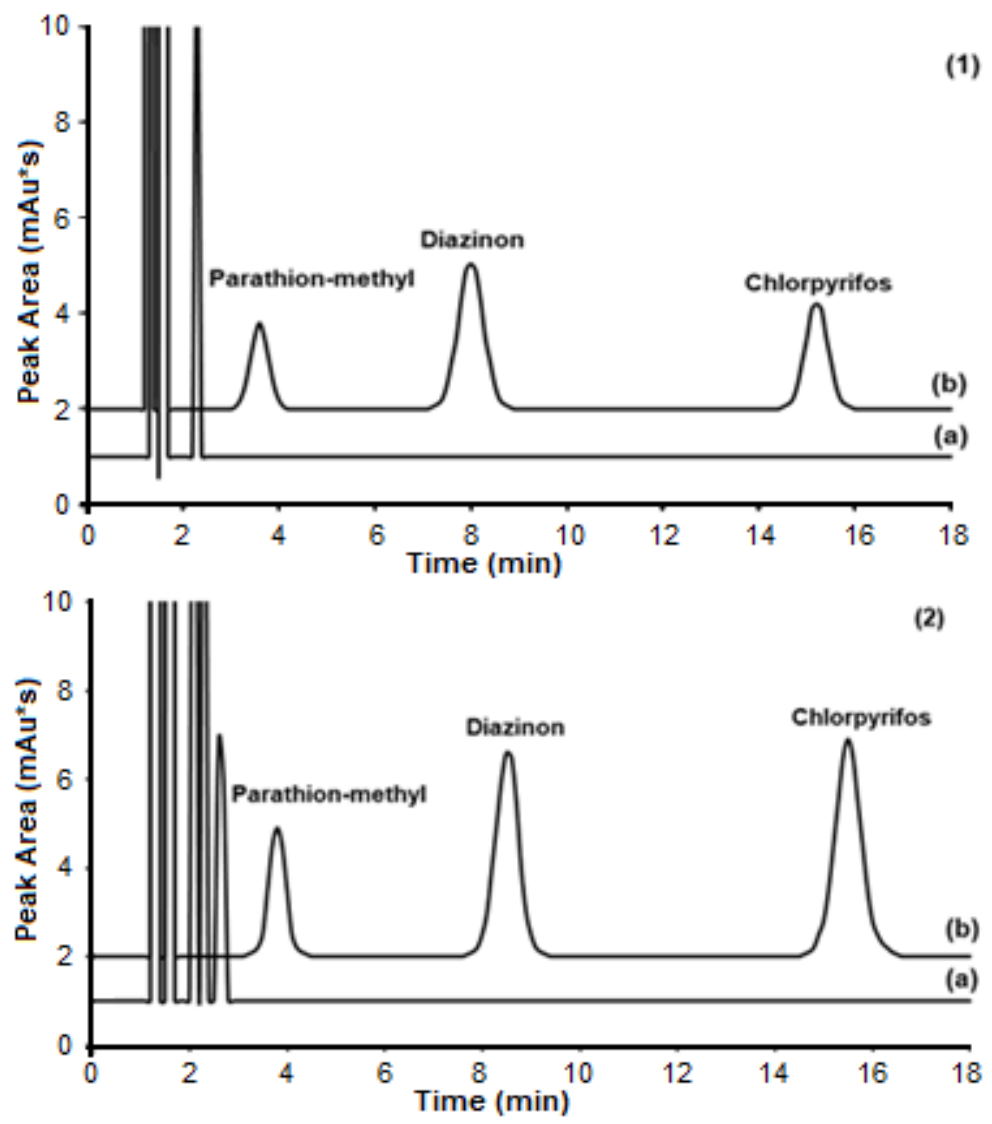

Fig 10. HPLC-UV chromatogram for the (a) unspiked $\left(1 \mathrm{mg} \mathrm{L}^{-1}\right)$ and (b) spiked of real samples of (1) grape and (2) strawberry 
Table 5. Recovery and RSD\% of OPPs analysis in grape and strawberry samples using developed MCM-41 and $\mathrm{Fe}_{3} \mathrm{O}_{4}-\mathrm{MCM}-41$

\begin{tabular}{|c|c|c|c|c|c|}
\hline \multirow{2}{*}{ Sorbent } & \multirow{2}{*}{ Sample } & \multirow{2}{*}{$\begin{array}{l}\text { Spiked level } \\
\left(\mathrm{mg} \mathrm{L}^{-1}\right)\end{array}$} & \multicolumn{3}{|c|}{$\%$ Recovery (RSD\%, n=3) } \\
\hline & & & Chlorpyrifos & Diazinon & Parathion methyl \\
\hline \multirow{4}{*}{ MCM-41 } & \multirow[t]{2}{*}{ Strawberry } & 0 & nd & nd & nd \\
\hline & & 1 & $110.7(5.7)$ & $101.4(2.0)$ & $108.9(5.2)$ \\
\hline & \multirow{2}{*}{ Grapes } & 0 & nd & nd & nd \\
\hline & & 1 & $112.4(4.6)$ & $107.2(0.7)$ & $73.3(4.8)$ \\
\hline \multirow{4}{*}{$\mathrm{Fe}_{3} \mathrm{O}_{4}-\mathrm{MCM}-41$} & \multirow{2}{*}{ Strawberry } & 0 & nd & nd & nd \\
\hline & & 1 & $101.8(1.8)$ & $83.5(3.0)$ & $109.6(4.3)$ \\
\hline & \multirow{2}{*}{ Grapes } & 0 & nd & nd & nd \\
\hline & & 1 & $118.3(5.5)$ & $108.8(1.3)$ & $115.3(1.2)$ \\
\hline
\end{tabular}

Table 6. Comparison of the current study with other recent solid-based extraction techniques that used for determination of OPPs in fruits and vegetable sample preparation

\begin{tabular}{llllccc}
\hline Adsorbent & Method & Detector & Matrix & LODs & Recovery (\%) & References \\
\hline $\mathrm{Fe}_{3} \mathrm{O}_{4}-\mathrm{MCM}-41$ & MSPE & HPLC-UV & Fruits & $0.02 \mathrm{mg} \mathrm{L}^{-1}$ & $85-120$ & This study \\
${\mathrm{MG} @ S i \mathrm{O}_{2} \text {-TMSPEDc }}_{\mathrm{Fe}_{3} \mathrm{O}_{4} @ \mathrm{G}-\mathrm{TEOS}-\mathrm{MTMOS}}$ & MSPE & GC- $\mu$ ECD & Fruits & $0.20 \mathrm{~g} \mathrm{~kg}^{-1}$ & $82-113$ & {$[56]$} \\
$\mathrm{Fe}_{3} \mathrm{O}_{4} @ \mathrm{SiO}_{2} @ G O-P E A$ & MSPE & GC-ECD & Water & $1.44 \mathrm{pg} \mathrm{mL}^{-1}$ & $83-105$ & {$[57]$} \\
$\mathrm{C}-\mathrm{G} / \mathrm{Fe}_{3} \mathrm{O}_{4}$ & GPME & HPLC-UV & Water and vegetables & $0.02 \mu \mathrm{g} \mathrm{L}^{-1}$ & $94.6-104.2$ & {$[58]$} \\
$\mathrm{GCB} / \mathrm{PSA} / \mathrm{Fe} \mathrm{O}_{3}-\mathrm{O}_{4}$ & DSPE & GC-MS & Vegetables & $5.0 \mathrm{ng} \mathrm{L}^{-1}$ & $>70$ & {$[59]$} \\
Molecular imprinted polymer & SPE & GC-MS & Fruits & $1.30 \mathrm{ng} \mathrm{L}^{-1}$ & $70.3-114.1$ & {$[60]$} \\
PDMS-TEOS & SBSE & GC-TCD & Vegetables & $0.83 \mathrm{\mu g} \mathrm{L}^{-1}$ & $89.7-99.7$ & {$[61]$} \\
\hline
\end{tabular}

Organophosphorus Pesticides (OPPs), limit of detection (LOD), magnetic solid phase extraction (MSPE), solid phase microextraction (MSPE), dispersive solid phase extraction (DSPE), solid phase extraction (SPE), stir bar sorptive extraction (SBSE), high-performance liquid chromatography-ultraviolet detector (HPLC-UV), gas chromatography-electron capture detector (GC-ECD), gas chromatography mass spectrometry (GC-MS), gas chromatography thermal conductivity (GC-TCD)

\section{Real Sample Analysis}

In order to assess the applicability of the proposed $\mathrm{Fe}_{3} \mathrm{O}_{4}$-MCM-41, MSPE method OPPs pesticides were isolated to strawberry and grape as real model samples. Prior to that, the real samples were treated in accordance with the procedure in preparing samples and were then spiked with the OPP standard solution with level $1 \mathrm{mg} \mathrm{L}^{-1}$. Each sample was analyzed three times using the HPLC/UV. The same process was applied to unspiked samples. The obtained HPLC chromatograms for strawberry and grape samples (spiked and unspiked) are illustrated in Fig. 10(1) and 10(2). It was shown that the unspiked samples for the selected pesticides were not detected. Besides, Table 5 shown good recoveries of the method were observed in the range of $85-120 \%$ with good repeatability \%RSD $(<10 \%, \mathrm{n}=3)$ for the selected pesticides in both strawberry and grape samples. Additionally, RSDs for triple extraction was more than $10 \%$ for the analyte in the real samples.

\section{Comparison with Other Methods}

Literature research of analytical performances on the determination of OPPs pesticide in various samples was conducted to compare the properties of the proposed method with those of the reputed studies. As illustrated in Table 6, the developed MSPE method offers LOD better than SPE, DSPE, and comparable with that of SPME and MSPE methods which demonstrated considerable lower LODs. However, the LODs of the current MSPE procedure is lower than MLRs $\left(10 \mathrm{mg} \mathrm{L}^{-1}\right)$ and offers an easier and faster procedure for the simultaneous extraction of selected pesticides from fruit samples. 


\section{- CONCLUSION}

The combined advantages of the large surface area of MCM-41 and magnetic properties of $\mathrm{Fe}_{3} \mathrm{O}_{4}$ make the successfully synthesized $\mathrm{Fe}_{3} \mathrm{O}_{4}-\mathrm{MCM}-41$ a promising sorbent for microextraction of OPPs pesticides in fruit samples. Outstanding relative recovery (85-120\%) and low LOD (0.04-0.20 $\left.\mathrm{mg} \mathrm{L}^{-1}\right)$ with method precision (RSD\%) of (2.6 to 9.0\%, $\mathrm{n}=3$ ) for selected OPPs in reals samples were achieved. These results proved that the newly synthesized of $\mathrm{Fe}_{3} \mathrm{O}_{4}-\mathrm{MCM}-41$ is a versatile adsorbent for the preconcentration of OPPs pesticides as compared to those of MCM-41. The field studies also supported the effectiveness of this new magnetic nanocomposite adsorbent which could be used and has good potential for the extraction of selected pesticides from real fruit samples.

\section{- ACKNOWLEDGMENTS}

The authors wish to thank Universiti Teknologi MARA for the facilitation and the Ministry of Education Malaysia for their financial supports through vote number 600-IRMI/FRGS 5/3 (FRGS/1/2017/STG01/UITM/02/8).

\section{- REFERENCES}

[1] Nodeh, H.R., Wan Ibrahim, W.A., Kamboh, M.A., and Sanagi, M.M., 2015, Dispersive graphene-based silica coated magnetic nanoparticles as a new adsorbent for preconcentration of chlorinated pesticides from environmental water, RSC $A d v ., 5$ (93), 76424-76434.

[2] Farajzadeh, M.A., Mogaddam, M.R.A., Aghdam, S.R., Nouri, N., and Bamorrowat, M., 2016, Application of elevated temperature-dispersive liquid-liquid microextraction for determination of organophosphorus pesticides residues in aqueous samples followed by gas chromatography-flame ionization detection, Food Chem., 212, 198-204.

[3] Sanusi, A., Guillet, V., and Montury, M., 2004, Advanced method using microwaves and solidphase microextraction coupled with gas chromatography-mass spectrometry for the determination of pyrethroid residues in strawberries, J. Chromatogr. A, 1046 (1-2), 35-40.

[4] Ravelo-Pérez, L.M., Hernández-Borges, J., and Rodríguez-Delgado, M.Á., 2008, Multi-walled carbon nanotubes as efficient solid-phase extraction materials of organophosphorus pesticides from apple, grape, orange, and pineapple fruit juices, J. Chromatogr. A, 1211 (1-2), 33-42.

[5] Lambropoulou, D.A, and Albanis, T.A., 2003, Headspace solid-phase microextraction in combination with gas chromatography-mass spectrometry for the rapid screening of organophosphorus insecticide residues in strawberries and cherries, J. Chromatogr. A, 993 (12), 197-203.

[6] Soler, C., Mañes, J., and Picó, Y., 2005, Comparison of liquid chromatography using triple quadrupole and quadrupole ion trap mass analyzers to determine pesticide residues in oranges, $J$. Chromatogr. A, 1067 (1-2), 115-125.

[7] Maroni, M., Colosio, C., Ferioli, A., and Fait, A., 2000, Biological monitoring of pesticide exposure: A review. Introduction, Toxicology, 143 (1), 5-118.

[8] European Commission, EU Pesticides database, https://ec.europa.eu/food/plant/pesticides/eu-pesti cides-database/public/?event=homepage\&language $=\mathrm{EN}$, accessed on 07 January 2019.

[9] Ahmadi, K., Abdollahzadeh, Y., Asadollahzadeh, M., Hemmati, A., Tavakoli, H., and Torkaman, R., 2015, Chemometric assisted ultrasound leachingsolid phase extraction followed by dispersivesolidification liquid-liquid microextraction for determination of organophosphorus pesticides in soil samples, Talanta, 137, 167-173.

[10] Alves, A.C.H., Gonçalves, M.M.P.B., Bernardo, M.M.S., and Mendes, B.S., 2011, Determination of organophosphorous pesticides in the ppq range using a simple solid-phase extraction method combined with dispersive liquid-liquid microextraction, J. Sep. Sci., 34 (18), 2475-2481.

[11] Wan Ibrahim, W.A., Veloo, K.V., and Sanagi, M.M., 2012, Novel sol-gel hybrid methyltrimethoxysilane-tetraethoxysilane as solid 
phase extraction sorbent for organophosphorus pesticides, J. Chromatogr. A, 1229, 55-62.

[12] Timofeeva, I., Shishov, A., Kanashina, D., Dzema, D., and Bulatov, A., 2017, On-line in-syringe sugaringout liquid-liquid extraction coupled with HPLCMS/MS for the determination of pesticides in fruit and berry juices, Talanta, 167, 761-767.

[13] García, M.D.G., Dahane, S., Arrabal-Campos, F.M., Viciana, M.M.S., García, M.A., Fernández, I., and Galera, M.M., 2017, MCM-41 as novel solid phase sorbent for the pre-concentration of pesticides in environmental waters and determination by microflow liquid chromatography-quadrupole linear ion trap mass spectrometry, Microchem. J., 134, 181190.

[14] Saraji, M., Jafari, M.T., and Mossaddegh, M., 2016, Carbon nanotubes@silicon dioxide nanohybrids coating for solid-phase microextraction of organophosphorus pesticides followed by gas chromatography-corona discharge ion mobility spectrometric detection, J. Chromatogr. A, 1429, 3039.

[15] Della Pelle, F., Di Crescenzo, M.C., Sergi, M., Montesano, C., Di Ottavio, F., Scarpone, R., Scortichini, G., and Compagnone, D., 2016, Microsolid-phase extraction ( $\mu$-SPE) of organophosphorous pesticides from wheat followed by LC-MS/MS determination, Food Addit. Contam. A, 33 (2), 291-299.

[16] Hou, X., Lei, S.R., Qiu, S.T., Guo, L.A., Yi, S.G., and Liu, W., 2014, A multi-residue method for the determination of pesticides in tea using multi-walled carbon nanotubes as a dispersive solid phase extraction absorbent, Food Chem., 153, 121-129.

[17] Pavlović, D.M., Babić, S., Horvat, A.J.M., and Kaštelan-Macan, M., 2007, Sample preparation in the analysis of pharmaceuticals, TrAC, Trends Anal. Chem., 26 (11), 1062-1075.

[18] Samsidar, A., Siddiquee, S., and Shaarani, S.M., 2018, A review of extraction, analytical and advanced methods for determination of pesticides in environment and foodstuffs, Trends Food Sci. Technol., 71, 188-201.
[19] Šafař́ková, M., and Šafař́k, I., 1999, Magnetic solidphase extraction, J. Magn. Magn. Mater., 194 (1-3), 108-112.

[20] Bai, L., Mei, B., Guo, Q.Z., Shi, Z.G., and Feng, Y.Q., 2010, Magnetic solid-phase extraction of hydrophobic analytes in environmental samples by a surface hydrophilic carbon-ferromagnetic nanocomposite, J. Chromatogr. A, 1217 (47), 73317336.

[21] Krisbiantoro, P.A., Santosa, S.J., and Kunarti, E.S., 2017, Synthesis of fulvic acid-coated magnetite $\left(\mathrm{Fe}_{3} \mathrm{O}_{4}{ }^{-} \mathrm{FA}\right)$ and its application for the reductive adsorption of $\left[\mathrm{AuCl}_{4}\right]^{-}$, Indones. J. Chem., 17 (3), 453-460.

[22] Suyanta, Sutarno, Nuryono, Rusdiarso, B., Kunarti, E.S., Kusumastuti, H., and Kurnia, L., 2019, Superparamagnetic nanocomposite of magnetitechitosan using oleic acid as anti agglomeration and glutaraldehyde as crosslinkage agent, Indones. J. Chem., 19 (1), 133-142.

[23] Kamaruzaman, S., Sanagi, M.M., Yahaya, N., Wan Ibrahim, W.A., Endud, S., and Wan Ibrahim, W.N., 2017, Magnetic micro-solid-phase extraction based on magnetite-MCM-41 with gas chromatographymass spectrometry for the determination of antidepressant drugs in biological fluids, J. Sep. Sci., 40 (21), 4222-4233.

[24] Li, X.S., Zhu, G.T., Luo, Y.B., Yuan, B.F., and Feng, Y.Q., 2013, Synthesis and applications of functionalized magnetic materials in sample preparation, TrAC, Trends Anal. Chem., 45, 233247.

[25] Krížzek, M., Pechoušek, J., Tuček, J., Safárová, K., Medrík, I., and Machala, L., 2012, Iron oxide nanoparticle powders with high surface area, AIP Conf. Proc., 1489 (1), 88-94.

[26] Zhu, L., Pan, D., Ding, L., Tang, F., Zhang, Q., Liu Q., and Yao, S., 2010, Mixed hemimicelles SPE based on CTAB-coated $\mathrm{Fe}_{3} \mathrm{O}_{4} / \mathrm{SiO}_{2} \mathrm{NPs}$ for the determination of herbal bioactive constituents from biological samples, Talanta, 80 (5), 1873-1880.

[27] de Souza, K.C., Andrade, G.F., Vasconcelos, I., de Oliveira Viana, I.M., Fernandes, C., and de Sousa, 
E.M.B., 2014, Magnetic solid-phase extraction based on mesoporous silica-coated magnetic nanoparticles for analysis of oral antidiabetic drugs in human plasma, Mater. Sci. Eng., C, 40, 275-280.

[28] Manzano, M., Aina, V., Areán, C.O., Balas, F., Cauda, V., Colilla, M., Delgado M.R., and Vallet-Regí, M., 2008, Studies on MCM-41 mesoporous silica for drug delivery: Effect of particle morphology and amine functionalization, Chem. Eng. J., 137 (1), 3037.

[29] Duan, X., Qian, G., Zhou, X., Chen, D., and Yuan, W., 2012, MCM-41 supported CoMo bimetallic catalysts for enhanced hydrogen production by ammonia decomposition, Chem. Eng. J., 207-208, 103-108.

[30] Takeuchi, R., Shoji, A., and Sugawara, M., 2013, A solid phase-based nanopore sensing system for biomolecules using lipid-loaded mesoporous silica MCM-41 and a fluorescent dye, Sens. Actuators, B, 181, 29-37.

[31] Sayari, A., Hamoudi, S., and Yang, Y., 2005, Applications of pore-expanded mesoporous silica. 1. Removal of heavy metal cations and organic pollutants from wastewater, Chem. Mater., 17 (1), 212-216.

[32] Koesnarpadi, S., Santosa, S.J., Siswanta, D., and Rusdiarso, B., 2017, Humic acid coated $\mathrm{Fe}_{3} \mathrm{O}_{4}$ nanoparticle for phenol sorption, Indones. J. Chem., 17 (2), 274-283.

[33] Muflikhah, M., Rusdiarso, B., Putra, E.G.R., and Nuryono, 2017, Modification of silica coated on iron sand magnetic material with chitosan for adsorption of $\mathrm{Au}(\mathrm{III})$, Indones. J. Chem., 17 (2), 264-273.

[34] Yokoi, T., Yoshitake, H., and Tatsumi, T., 2004, Synthesis of mesoporous silica by using anionic surfactant, Stud. Surf. Sci. Catal., 154, 519-527.

[35] Maddah, B., and Shamsi, J., 2012, Extraction and preconcentration of trace amounts of diazinon and fenitrothion from environmental water by magnetite octadecylsilane nanoparticles, J. Chromatogr. A, 1256, 40-45.

[36] Chen, H., Deng, C., and Zhang, X., 2010, Synthesis of $\mathrm{Fe}_{3} \mathrm{O}_{4} @ \mathrm{SiO}_{2} @ \mathrm{PMMA}$ core-shell-shell magnetic microspheres for highly efficient enrichment of peptides and proteins for MALDI-ToF MS analysis, Angew. Chem. Int. Ed., 49 (3), 607-611.

[37] Kamaruzaman, S., Sanagi, M.M., Endud, S., Wan Ibrahim, W.A., and Yahaya, N., 2013, MCM-41 solid phase membrane tip extraction combined with liquid chromatography for the determination of non-steroidal anti-inflammatory drugs in human urine, J. Chromatogr. B, 940, 59-65.

[38] Taib, N.I., Endud, S., and Katun, M.N., 2011, Functionalization of mesoporous Si-MCM- 41 by grafting with trimethylchlorosilane, Int. J. Chem., 3 (3), 2-10.

[39] Bhuyan, D., Saikia, M., and Saikia, L., 2015, Magnetically recoverable $\mathrm{Fe}_{3} \mathrm{O}_{4} @ S B A-15: \quad A n$ improved catalyst for three component coupling reaction of aldehyde, amine, and alkyne, Catal. Commun., 58, 158-163.

[40] Liu, Y., Qiu, J., Jiang, Y., Liu, Z., Meng, M., Ni, L., Qin, C., and Peng, J., 2016, Selective Ce(III) ionimprinted polymer grafted on $\mathrm{Fe}_{3} \mathrm{O}_{4}$ nanoparticles supported by SBA-15 mesopores microreactor via surface-initiated RAFT polymerization, Microporous Mesoporous Mater., 234, 176-185.

[41] Hou, M., Zang, X., Wang, C., and Wang, Z., 2013, The use of silica-coated magnetic graphene microspheres as the adsorbent for the extraction of pyrethroid pesticides from orange and lettuce samples followed by GC-MS analysis, J. Sep. Sci., 36 (19), 3242-3248.

[42] Mahpishanian, S., Sereshti, H., and Baghdadi, M., 2015, Superparamagnetic core-shells anchored onto graphene oxide grafted with phenylethyl amine as a nano-adsorbent for extraction and enrichment of organophosphorus pesticides from fruit, vegetable and water samples, J. Chromatogr. A, 1406, 48-58.

[43] Kiselev, A.V., Lygin, V.I., and Starodubceva, R.V., 1972, Spectral and energetic aspects of water adsorption by Li-, Na-, K- and Cs-X zeolites, J. Chem. Soc., Perkin Trans. 1, 68 (0), 1793-1798.

[44] Ulu, A., Noma, S.A.A., Koytepe, S., and Ates, B., 2018, Magnetic $\mathrm{Fe}_{3} \mathrm{O}_{4} @ M C M-41 \quad$ core-shell 
nanoparticles functionalized with thiol silane for efficient 1-asparaginase immobilization, Artif. Cells Nanomed. Biotechnol., 46 (Suppl. 2), 1035-1045.

[45] Alam, N., and Mokaya, R., 2008, Crystalline mesoporous silica materials from layered silicate precursors, J. Mater. Chem., 18, 1383-1391.

[46] Hui, K.S., and Chao, C.Y.H., 2006, Synthesis of MCM-41 from coal fly ash by a green approach: Influence of synthesis pH, J. Hazard. Mater., 137 (2), 1135-1148.

[47] Fellenz, N.A., De Berti, I.O.P., Soldati, A.L., Stewart, S.J., Marchetti, S.G., and Bengoa, J.F., 2015, Changes on structural and magnetic properties of maghemite nanoparticles during their coverage with MCM-41, Ceram. Int., 41 (10), 15057-15066.

[48] Abdollahi-Alibeik, M., and Rezaeipoor-Anari, A., 2016, $\mathrm{Fe}_{3} \mathrm{O}_{4} @ \mathrm{~B}-\mathrm{MCM}-41$ : A new magnetically recoverable nanostructured catalyst for the synthesis of polyhydroquinolines, J. Magn. Magn. Mater., 398, 205-214.

[49] Arica, T.A., Ayas, E., and Arica, M.Y., 2017, Magnetic MCM-41 silica particles grafted with poly(glycidylmethacrylate) brush: Modification and application for removal of direct dyes, Microporous Mesoporous Mater., 243, 164-175.

[50] Kumar, D., Schumacher, K., du Fresne von Hohenesche, C., Grün, M., and Unger, K.K., 2001, MCM-41, MCM-48 and related mesoporous adsorbents: Their synthesis and characterisation, Colloids Surf., A, 187-188, 109-116.

[51] Grün, M., Unger, K.K., Matsumoto, A., and Tsutsumi, K., 1999, Novel pathways for the preparation of mesoporous MCM-41 materials: control of porosity and morphology, Microporous Mesoporous Mater., 27 (2-3), 207-216.

[52] Teo, H.T., Siah, W.R., and Yuliati, L., 2016, Enhanced adsorption of acetylsalicylic acid over hydrothermally synthesized iron oxide-mesoporous silica MCM-41 composites, J. Taiwan Inst. Chem. Eng., 65, 591-598.

[53] See, H.H., Sanagi, M.M., Wan Ibrahim, W.A., and Naim, A.A., 2010, Determination of triazine herbicides using membrane-protected carbon nanotubes solid phase membrane tip extraction prior to micro-liquid chromatography, $J$. Chromatogr. A, 1217 (11), 1767-1772.

[54] Lee, T.P., Saad, B., Ng, E.P., and Salleh, B., 2012, Zeolite Linde Type L as micro-solid phase extraction sorbent for the high performance liquid chromatography determination of ochratoxin A in coffee and cereal, J. Chromatogr. A, 1237, 46-54.

[55] Amani, M.A., Latifi, A.M., Tahvildari, K., and Karimian, R., 2017, Removal of diazinon pesticide from aqueous solutions using MCM-41 type materials: isotherms, kinetics, and thermodynamics, Int. J. Environ. Sci. Technol., 15 (6), 1301-1312.

[56] Nodeh, H.R., Wan Ibrahim, W.A., Kamboh, M.A., and Sanagi, M.M., 2017, New magnetic graphenebased inorganic-organic sol-gel hybrid nanocomposite for simultaneous analysis of polar and non-polar organophosphorus pesticides from water samples using solid-phase extraction, Chemosphere, 166, 21-30.

[57] Nodeh, H.R., Sereshti, H., Gaikani, H., Kamboh, M.A., and Afsharsaveh, Z., 2017, Magnetic graphene coated inorganic-organic hybrid nanocomposite for enhanced preconcentration of selected pesticides in tomato and grape, $J$. Chromatogr. A, 1509, 26-34.

[58] Mahpishanian, S., and Sereshti, H., 2016, Threedimensional graphene aerogel-supported iron oxide nanoparticles as an efficient adsorbent for magnetic solid phase extraction of organophosphorus pesticide residues in fruit juices followed by gas chromatographic determination, $J$. Chromatogr. A, 1443, 43-53.

[59] Razmi, H., and Jabbari, M., 2015, Development of graphene-carbon nanotube-coated magnetic nanocomposite as an efficient sorbent for HPLC determination of organophosphorus pesticides in environmental water samples, Int. J. Environ. Anal. Chem., 95 (14), 1353-1369.

[60] Luo, Y.B., Zheng, H.B., Jiang, X.Y., Li, X., Zhang, H.F., Zhu, F.P., Pang, Y.Q., and Feng, Y.Q., 2015, Determination of pesticide residues in tobacco 
using modified QuEChERS procedure coupled to on-line gel permeation chromatography-gas chromatography/tandem mass spectrometry, Chin. J. Anal. Chem., 43 (10), 1538-1544.

[61] Wan Ibrahim, W.A., Wan Ismail, W.N., and Sanagi, M.M., 2013, Selective and simultaneous solid phase extraction of polar and non-polar organophosphorus pesticides using sol-gel hybrid silica-based sorbent, Jurnal Teknologi, 62 (3), 83-87.

[62] Guan, H., Brewer, W.E., Garris, S.T., and Morgan, S.L., 2010, Disposable pipette extraction for the analysis of pesticides in fruit and vegetables using gas chromatography/mass spectrometry, $J$. Chromatogr. A, 1217 (12), 1867-1874. 